\title{
Embryology and genetics of primary vesico-ureteric reflux and associated renal dysplasia
}

\author{
Luisa Murer • Elisa Benetti • Lina Artifoni
}

Received: 29 August 2006 /Revised: 7 November 2006 / Accepted: 7 November 2006 / Published online: 10 January 2007

(C) IPNA 2007

\begin{abstract}
Congenital anomalies of the kidney and urinary tract, as well as primary vesico-ureteric reflux (VUR) and associated renal dysplasia, are the most relevant causes of end-stage renal failure in the pediatric population. In vivo and in vitro experimental studies have allowed the identification of several genes involved both in ureteric bud branching, ureteric elongation and insertion into the bladder, and in nephrogenesis. It has been proposed that both renal and ureteral abnormalities, as well as the associated renal hypo-dysplasia, may derive from a common mechanism as the result of a dysregulation of the normal developmental program. The large homologies between mice and the human genome suggest that the same genes could be involved both in rodent and human VUR. Furthermore, epidemiological observations suggest that not only syndromic but also isolated VUR is an inherited trait. Linkage analysis for homologous mouse genes in humans, genome-wide linkage studies in multigenerational families and association studies by polymorphisms support the hypothesis that VUR is genetically heterogeneous and is caused by a number of different genes
\end{abstract}

\footnotetext{
L. Murer $\cdot$ E. Benetti

Paediatric Nephrology, Dialysis and Transplant Unit, Department of Paediatrics, University of Padova, Padova, Italy

L. Murer $\cdot$ L. Artifoni

Laboratory of Paediatric Nephrology,

Department of Paediatrics, University of Padova,

Padova, Italy

L. Murer $(\bowtie)$

Paediatrics, University of Padova,

Via Giustiniani 3,

Padova 35128, Italy

e-mail: luisam@pediatria.unipd.it
}

acting with random environmental effects. The present teaching paper is an overview of the embryology and genetics of primary VUR and associated congenital reflux nephropathy.

Keywords Vesico-ureteric reflux · Embryology - Genetics . Kidney development

\section{Introduction}

Primary vesico-ureteric reflux (VUR) is a congenital defect of the urinary tract that causes urine to flow retrogradely from the bladder to the kidneys and it is not associated with any underlying neuromuscular or obstructive phenomenon [1]. Galen and Leonardo Da Vinci firstly described the oblique entry of ureter into the bladder that prevents the back-up of urine during bladder voiding. Later animal studies and human observations showed that developmental defects of the vesico-ureteric junction determining VUR include inadequate length of the intravesical ureter; the defective muscle layer of the trigone that encompasses the ureter adjoining the bladder and ectopic ureteral orifices within the trigone. VUR is a risk factor for upper urinary tract infections (UTI), causing pyelonephritis and renal scarring. Recurrent scarring and subsequent chronic renal damage may lead to progressive renal failure. VUR prevalence in the pediatric population is $1 \%$. NAPRTCS and European registries report that $8 \%$ of patients affected by VUR develop end-stage renal failure as a result of "reflux nephropathy", which accounts for $25 \%$ of end-stage renal disease [1-3]. Probably, many other individuals with VUR hidden in the population are affected by renal dysplasia and/or hypoplasia, which represent the major cause of end-stage renal failure. However, the prevention of 
UTI by clinical management (antibiotic prophylaxis) and/or by surgical correction of VUR have not significantly reduced the incidence of renal failure in these patients. Nonfunctioning renal units associated with VUR and end-stage renal failure are mostly hypo-dysplastic kidneys. The histological picture of dysplastic kidneys is characterized by the presence of renal parenchymal areas with various degrees of differentiation together with areas of undifferentiated nephrogenic mesenchyme and cartilaginous metaplasia, with or without different localized and extended tubular, ductal or glomerular cysts (Fig. 1). It is still controversial whether renal dysplasia is due to poor nephrogenic differentiation resulting from the back pressure effect of urine reflux on the developing fetal kidney. The degree of renal dysplasia does not correlate well with the severity of reflux. More recently, it has been proposed that both renal and ureteral abnormalities may derive from a common mechanism as the result of a dysregulation of the normal developmental program occurring very early during embryogenesis. Nephrourogenetic programming requires a complex sequential and temporal regulation of genes in terms of activation and repression. Experimental gene knock-out models have enabled the identification of some genes associated with VUR and reflux nephropathy, and mutations of murinehomologous human genes are responsible for syndromic forms of VUR-associated hypo-dysplasia.

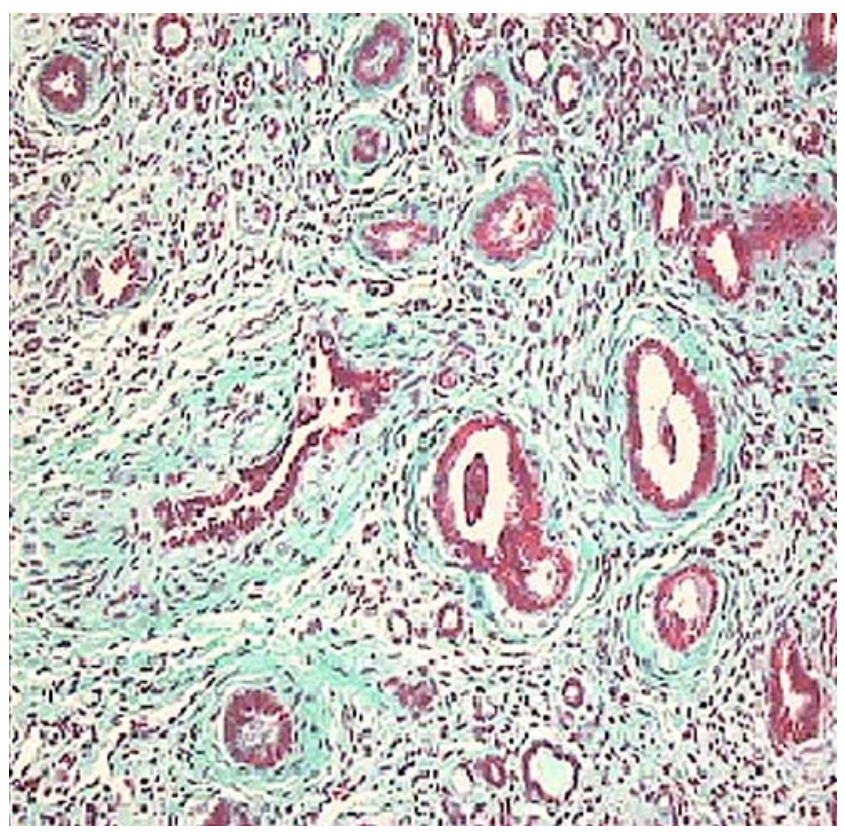

Fig. 1 Vesico-ureteric reflux-associated renal dysplasia. Dysplastic kidneys are characterized by the presence of renal parenchymal areas with various degrees of differentiation together with areas of undifferentiated nephrogenic mesenchyme and cartilaginous metaplasia, with or without different localized and extended tubular, ductal or glomerular cysts (Masson's Trichromic dye, $\times 40$ )

\section{Embryology of the kidney and urinary tract: the developmental theory of vesico-ureteric reflux}

In humans, as in other mammalian species, the kidney and ureter derive from a mesodermic tissue, the metanephros, which develops in close proximity to the mesonephric Wolffian duct, which extends to fuse with the cloaca, the urinary bladder precursor, and drains the transitory kidneys (pro- and mesonephroi; Fig. 2). The metanephros consists of two components: the ureteric bud and the metanephric mesenchyme. The former gives rise to the collecting ducts, the renal pelvis, the ureter, and the bladder trigone, while the latter differentiates into tubules (from distal tubules up to the glomerulus) and renal stroma. The development of both the components depends on a series of reciprocal inductive signals: at the end of the 4th week of gestation, metanephric mesenchyme induces the nearby Wolffian duct to evaginate an epithelial tube, the ureteric bud. This invades the metanephric mesenchyme, which in response condenses, proliferates, and undergoes an epithelial transformation at approximately the 5th week of gestation. In turn, the distal end of the ureteric bud branches to form the collecting system in response to contact with the stimulated metanephric mesenchyme. The proximal end of the ureteric bud remains attached to the mesonephric duct and elongates, becoming the distal ureter. The common nephric duct, the segment of the mesonephric duct that lies between the ureter and urogenital sinus or primitive bladder, undergoes programmed cell death. This permits the ureter to begin its incorporation into the bladder, during which it acquires a tunnel and a muscle layer that connects to the trigone [2].

In children with ureteral malformations, Mackie and Stephens observed two kinds of morphologic correlation: between the location of the ureteral orifice and the abnormalities of the ureter (i.e., VUR); and between the location of the ureteral orifice and the degree of kidney dysor hypoplasia (cited in [4]).

In the developing embryo, the ureteral orifice travels from its original budding site on the Wolffian duct to the final destination into the bladder as the Wolffian duct region is absorbed into the developing bladder. The final site of the ureteral orifice depends on the position where the ureteric bud exits from the mesonephric duct, which in turn depends on the time and location of the contact with the metanephric mesenchyme. For example, if the ureteric bud develops at a site too caudal along the Wolffian duct, its final location within the bladder will be abnormally cranial to the normal site (Fig. 3). This aberrancy results in the poor development of a "short" ureterovesical valve and VUR. Concurrently, the normal interaction between the ureteric bud and the metanephric blastema required for normal renal parenchyma growth and differentiation is also 
Fig. 2 Schematic representation of early events in kidney development (modified from [30])

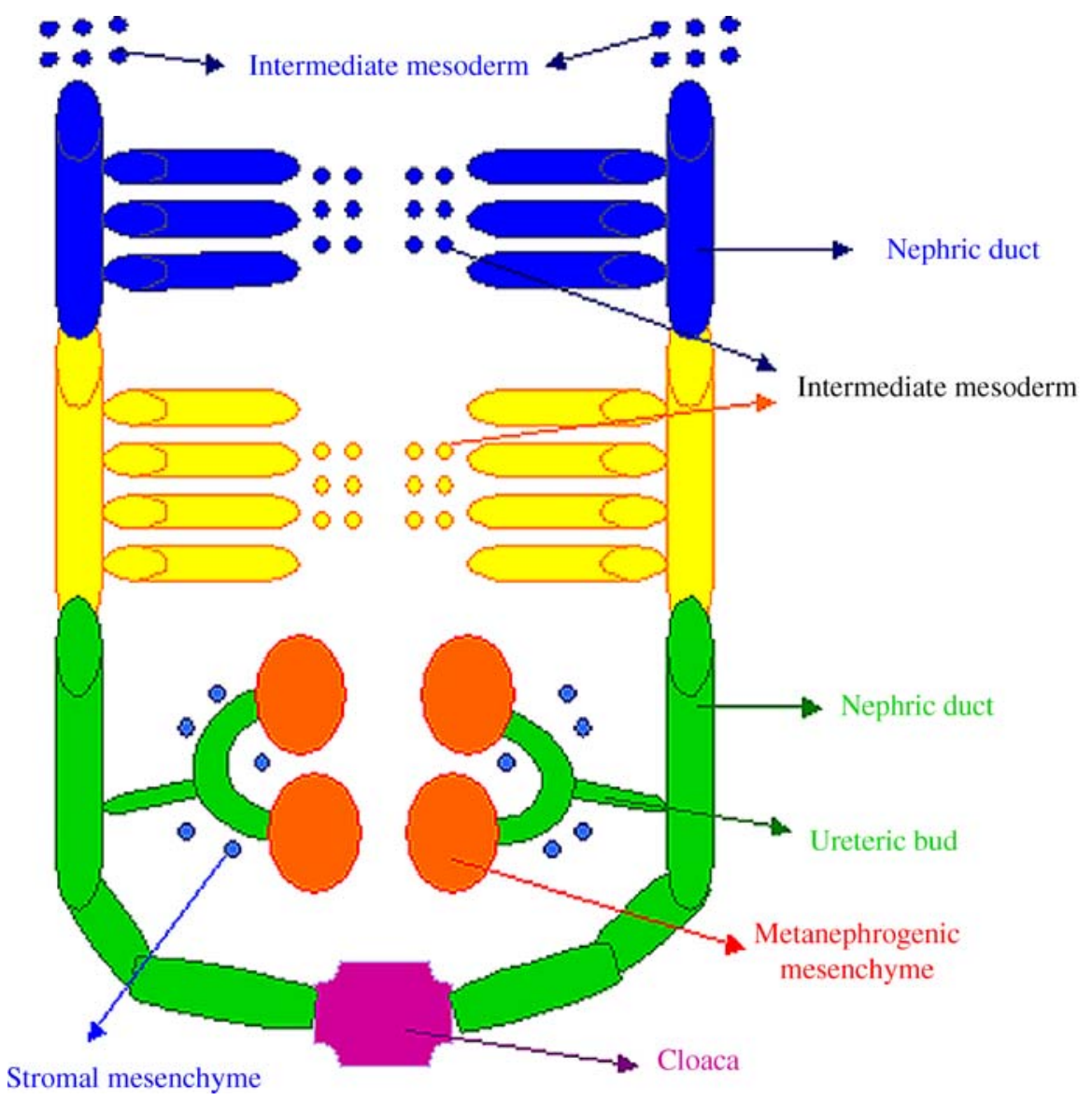

disrupted. The ureteral budding from an aberrant site contacts the metanephric mesenchyme at a point where mesenchymal cells are scarce, resulting in formation of hypoplastic and dysplastic kidneys. Renal hypo-dysplasia is not the result of urine reflux, but both kidney and ureter malformation derive from an aberrant contact between the ureteric bud and the metanephric blastema [4]. In the last decade, in vitro (organ culture) and in vivo (knock-out animal) studies and gene expression profile analysis on developing kidneys have provided essential data for the generation of hypotheses regarding the molecular control of nephrogenesis, enabling the identification of hundreds of implicated molecules, including growth/survival factors, cell adhesion molecules, and transcription factors.

\section{Molecular regulation of nephrogenesis and candidate genes of VUR}

Primum movens for metanephros development is the formation of the metanephrogenic mesenchyme [5]. This event depends on the prior activation in the intermediate mesoderm of transcription factors produced by normally formed pronephros and mesonephros, such as Lim-1, Pax2, Eya-1, and Foxc-1 (Fig. 4) [6]. Once it has formed, the mesenchyme secretes Gdnf (glial-derived neurotrophic factor), inducing the nearby Wolffian duct to give out the ureteric bud, which invades the metanephric blastema and begins its branching and elongation. In lim-1-/- mice, the intermediate mesenchyme is disorganized and fails to express other proteins necessary for kidney development such as $P a x-2$. This is a transcription factor expressed in mesonephros and later in metanephros. Pax-2-/- mice fail to form any kidney [7]. In knock-out mice for the transcriptional co-activator Eya-1, the caudal end of the intermediate mesenchyme never produces Gdnf and so never initiates metanephric development. Foxc-1-/- mice show a disorganization of mesonephroi and their metanephrogenic mesenchyme forms too anteriorly, causing the ureter to be positioned further forward than usual, or an additional ureter to form on the same side. More recently, it has been reported that mesenchymal expression of Sall1 transcription factor is necessary for early inductive events in murine kidney [6]. When metanephric mesenchyme is formed, the primary signal that it emanates is the growth factor Gdnf, which stimulates the ureteric bud out-growing from the Wolffian duct through its receptor $c$-Ret (retinoic acid receptor), a tyrosine kinase, and its $G f r-1 \alpha$ coreceptor, both expressed by the ureteric bud. This signaling system continues to operate after bud induction, sustaining its intra- 
Fig. 3 Dynamics of the kidney and ureteral development according to the "bud theory". Relationship between ureteric bud position on the Wolffian duct to the nephrogenic blastema and orifice positions in the bladder and urethra. $A$ Ectopic bud orifice on the lateral and cranial end of the extended hemitrigone (site $a$ ), resulting in VUR. $B$ Normal ureteric bud orifice $B$ on the corner (site $b$ ). $C$ Ectopic bud orifice on the caudal extremity of the bladder. The metanephric mesenchyme is well differentiated when interacting with a bud at the normal site $B$ but sparse and poorly differentiated around bud $A$ and $C$ (from [4])

\section{Normal (B) And Ectopic (A, C) Budding of the Ureter}

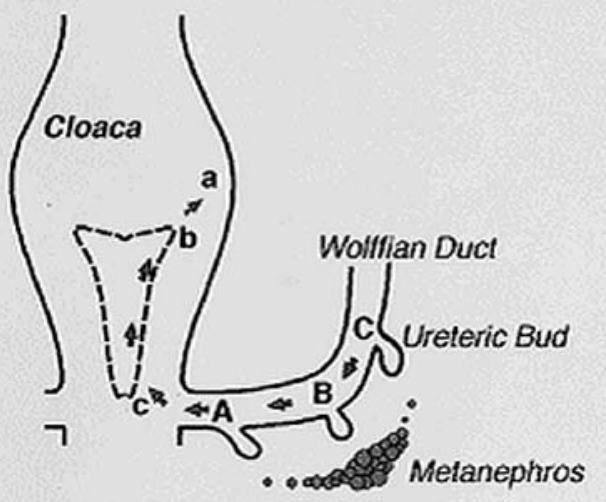

Results of Budding at A

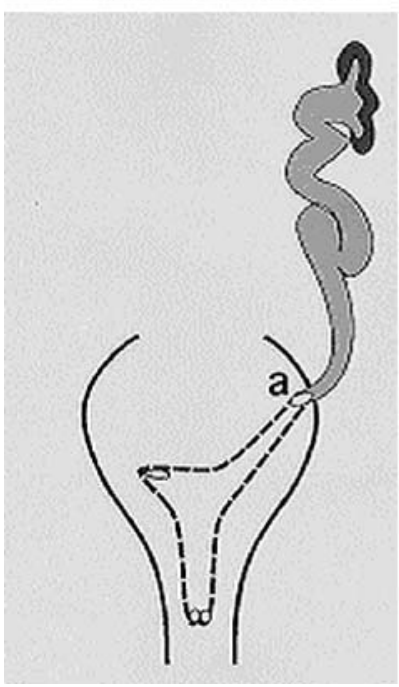

mesenchymal arborization. The importance of the Gdnf/Ret pathway has been confirmed by the absence of kidneys in homozygous null mutant mice and by the absence of ureteric out-growth in experiments with blocking antibodies to Gdnf in culture of whole metanephric rudiments. Conversely, the addition of Gdnf to cultured metanephroi induces ectopic ureters. The receptor tyrosine kinase
Results of Budding at $B$

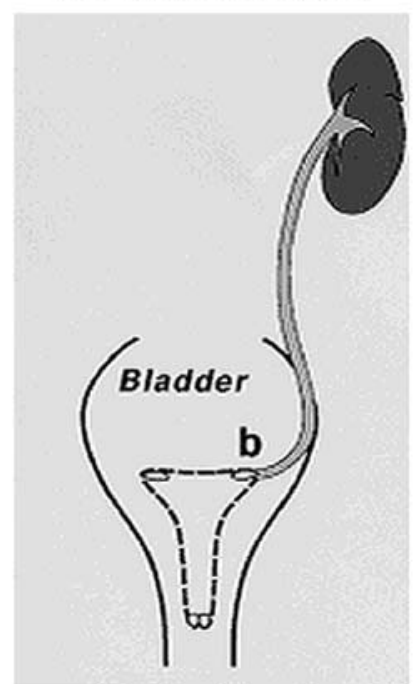

Results of Budding at $\mathrm{C}$

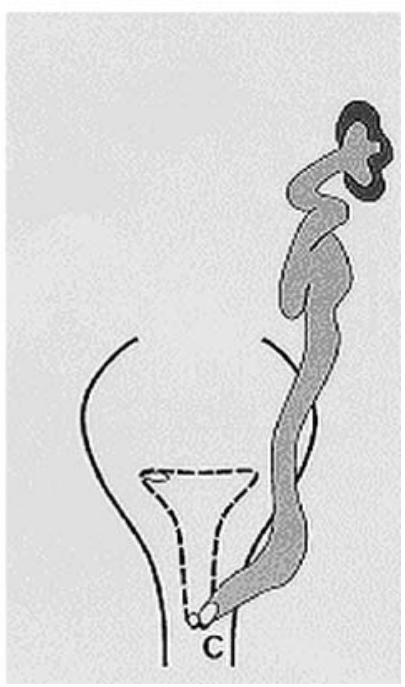

antagonist Spryl negatively regulates the Gdnf/Ret-signaling pathway, such that in Spryl-/- mice the mesonephric duct is more sensitive to $G d n f$ and develops multiple ureteric buds $[5,6,8]$. In the HoxB7/Ret transgenic mouse Ret is over-expressed and the kidneys are small and cystic with grossly dilated ureters and a shorter intravesical tunnel, into which urine flows retrogradely from the

Fig. 4 Overview of genes involved in ureteric bud induction. $M M$ metanephric mesenchyme, $U B$ ureteric bud, $W D$ wolffian duct. See text for details (modified from [8])
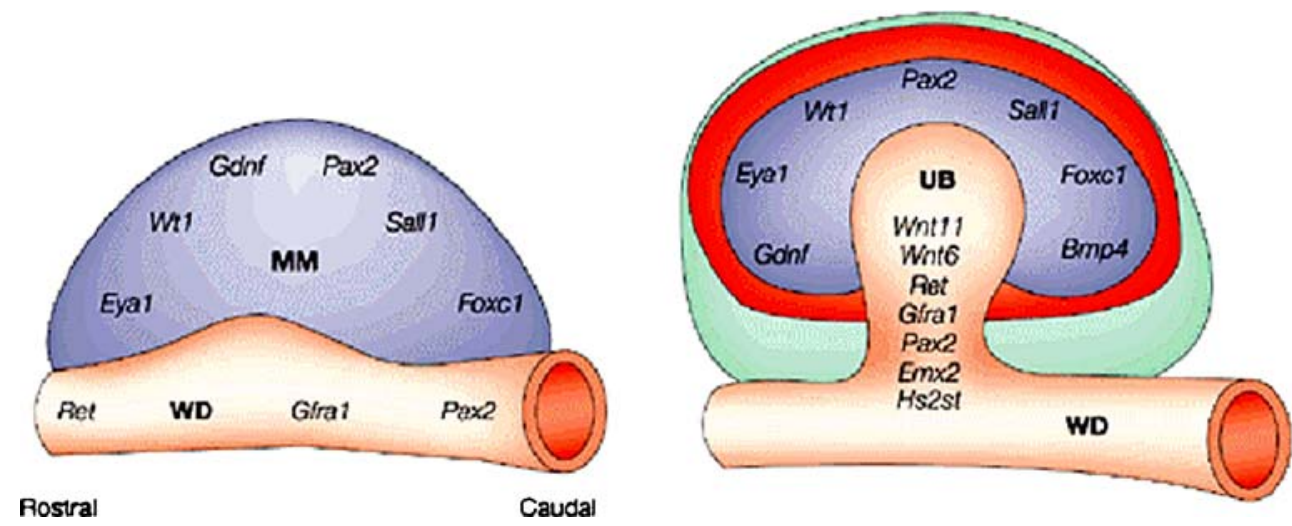
bladder, resulting in postnatal VUR. Mice lacking either Ret, or an enzyme required for retinoic acid synthesis have malformed kidneys and defects in the distal ureter: in males, the ureter remains attached to the mesonephric duct, which forms the deferent duct in adults, while it inserts into the uterus in females. Signaling through vitamin A and Gdnf/Ret is required for the common nephric duct to contact the urogenital sinus and undergo apoptosis during the formation of the vesico-ureteric junction.

Expression of Ret by the ureteric bud requires other transcription factors such as $E m x-2$; bud development also depends on the mesenchyme-derived growth factor $\mathrm{Hgf}$ with its tyrosine kinase receptor $c$-Met. Members of the bone morphogenetic protein family exert varied effects on ureteric bud development: Bmp-2 acts as a powerful inhibitor of ureteric bud branching, restricting ramification to the terminal part of the bud; Bmp-4 expression in the stroma around the ureteric bud and along the stalk of the ureteric bud prevents the ureteric bud from forming too early, or anteriorly along the Wolffian duct and bifurcating before it invades the mesenchyme. Heterozygous $b m p-4+/-$ mice are animal models of vesico-ureteric junction abnormalities, which are often associated with bifid ureters. Many other growth factors, such as $T g f-\beta$ and $F g f$, and some components of the extracellular matrix, such as glycosaminoglycans and proteins, partly secreted by the bud and partly by the surrounding mesenchyme, have been found to participate in ureteric development.

Recently, 20 different transcripts have been identified as potentially important in metanephros development by microarray analyses on the rat tips of the ureteric tree. One of these is the cytokine-like factor 1 (Cfl-1), which induces mature nephron structures expressing glomerular and tubular markers when applied to isolated rat metanephric mesenchyme. The isolation of metanephrogenic mesenchyma from the ureteric bud would result in its death, but this fate is reversed by factors secreted by the bud, such as Tgf- $\alpha$, Timp-2, Egf, and $F g f-2$. Other factors, such as Lif and Tgf- $\beta 2$, cooperate with the previously induced clumps of mesenchyme cells to differentiate into nephrons, while Bmp-7 appears to lead them instead to form stroma [9]. As nephrons form, they express transcription factors such as Pax-2 and Hoxa-11, and condense and secrete $W n t-4$, which acts in an autocrine loop to stimulate its own synthesis and is required for mesenchymal cells to differentiate into epithelia. As well as acquiring their basic epithelial character, nephron cells have to differentiate to produce specialized functional regions. Maintained expression of Pax-2 is necessary for nephron tubule elongation, but its inhibition by $W t-1$ is fundamental for normal glomerular development. While Pax-2 homozygous null mutant mice develop renal hypo-dysplasia associated with various urinary tract malformations such as VUR, Pax-2 over-expression induces hyper-proliferative tubular cysts and a failure of mature glomerular development [10]. Many other proteins have been recognized to be involved in region differentiation of the nephron, such as Lmx-1b, Notch-2, Jagged-1, and Hnf-1, but a larger number of molecules with similar activities are still to be identified [3]. Figure 5 summarizes candidate genes for VUR and urinary tract malformations, and their genomic loci in mice.

Briefly, experimental models suggest that:

1. Developmental anomalies of the urinary tract are due to alterations perturbing the complex gene network that controls nephrourogenesis

2. The different phenotypes of renal and ureteric malformations may depend on the stage of nephrogenesis at which the alteration of the developmental program occurs: renal agenesis should be the result of the complete lack of metanephric induction by the ureteric bud; different degrees of dysplasia associated with urinary tract anomalies, such as VUR, should originate from the disruption of the normal ureteral branching and elongation, and the epithelial differentiation processes

3. A mutation affecting a single gene may result in different phenotypes, and mutations of different genes can result in the same disease

4. Dysregulation of an upstream gene of a metabolic pathway may alter the function of one or more downstream genes of that very metabolic pathway or of other related ones, involved in the determination of a specific phenotype (modifier gene)

It has also been shown that not only a lack of transcription of a gene, but also its overexpression, may be responsible for a disease.

\section{Genetic basis of VUR}

On the basis of human homolog gene knock-out mice models, which have identified a series of genes responsible for the normal or abnormal development of the urinary tract, a genetic basis for VUR and the associated renal dysplasia may be hypothesized in humans. VUR can occur as part of complex syndromes with an inherited pattern [11]. The genetic hypothesis is also supported by epidemiological evidence: isolated VUR has a high incidence in the population with ethnic differences between affected and non-affected individuals (reduced incidence in African Americans); monozygotic twins show $80-100 \%$ concordance for VUR compared with $35-50 \%$ concordance in dizygotic twins; $30-50 \%$ of the siblings of affected children have VUR and familial clustering of isolated VUR is well described. 


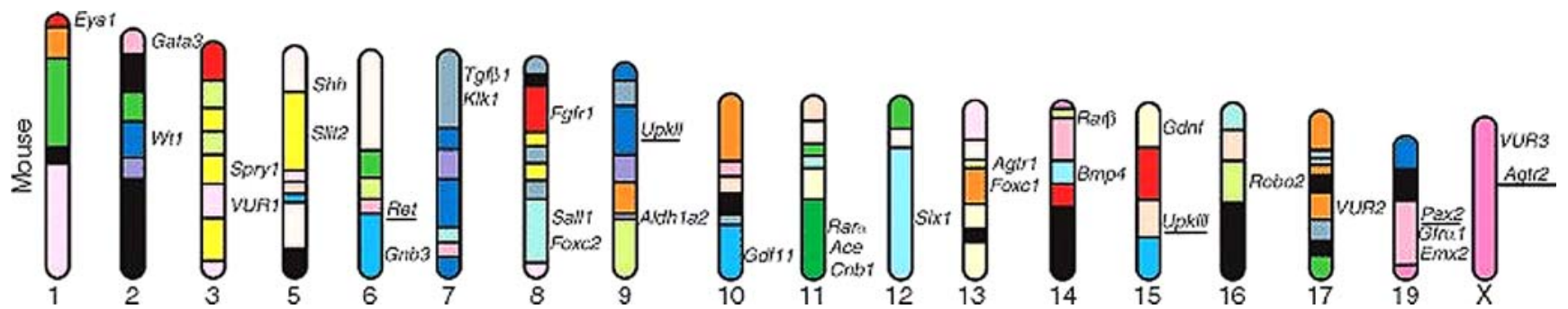

Fig. 5 Candidate genes for vesico-ureteric reflux and urinary tract malformations and their genomic loci in mice (modified from [3])

In humans, as in mice, renal tract disorders occur with multiorgan malformation syndromes commonly affecting eyes and the central nervous, cardiovascular, and skeletal systems. Although individually rare, malformation syndromes collectively account for significant morbidity. Some are associated with gross chromosomal anomalies such as monosomy of chromosome $\mathrm{X}$, trisomy of chromosomes 13 , 18 , and 21 ; deletion of chromosomes $4 \mathrm{p}, 5 \mathrm{p}$, and $11 \mathrm{p}$; and several microdeletions such as chromosome $7 \mathrm{q}, 22 \mathrm{q} 11$, and 17p11.2. However, cytogenetic rearrangements are absent in most children born with syndromic urinary tract malformations. Table 1 summarizes human syndromes with VUR with their own inheritance pattern. Several syndromes have an identified gene (mice homolog), whose protein and function are also well known.

\section{Mendelian inherited syndromes with renal hypo/ dysplasia and VUR}

Renal-coloboma syndrome (RCS; OMIM 120330) is an autosomal dominant disorder characterized by optic nerve coloboma and renal anomalies, which commonly include renal hypoplasia and VUR. Auditory, CNS, and skin/joint anomalies may also be present. Renal and/or ocular manifestations are found in all patients, although a marked phenotypic variability has been observed. Sanyanusin first described heterozygous mutations of the PAX2 gene in patients with renal-coloboma syndrome [12]. An experimental model revealed that Pax-2-/- mutant mice lack kidneys and a ureter because the ureteric bud fails to branch from the mesonephric duct, while haplo-insufficiency (a lack of functional protein due to a mutated allele) in Pax-2 $+/-$ mutant mice is associated with renal hypoplasia and sometimes hydro-ureteronephrosis consistent with the presence of vesico-ureteric reflux [13]. Human PAX2 gene maps to chromosome 10q24-25 and comprises 12 exons. The first four exons encode a highly conserved DNA-binding domain, essential for transcription factor function, whose role during kidney and ureter development has been discussed above. To date, many different PAX2 mutations have been reported in humans, most frequently affecting exon 2 (http://www.hgu.mrc.ac.uk/Softdata/PAX2). Phenotypic variability has been observed not only with differing mutations, but also with the same mutation and within the same family, and PAX2 mutations have also been reported in isolated renal hypoplasia and in VUR [14].

Branchio-oto-renal syndrome (BOR; OMIM 113650) segregates as an autosomal dominant disease with incomplete penetrance and variable expressivity. Common phenotypic features comprise deafness, preauricular pits/tags, branchial and external ear malformations, and renal anomalies including renal hypo/dysplasia with abnormalities of the collecting system and VUR. In 1997, Abdelhak identified mutations in a novel gene called EYA1 in seven affected patients [15]. In further reports, 51 different mutations of EYAl (http://www.medicine.uiowa. edu/pendredandbor) have been associated with BOR syndrome, including point mutations and complex rearrangements, which may involve every exon and seem to be randomly scattered throughout the gene. There is no single common mutation, but most mutations are unique to individual families. EYA1 maps on chromosome 8q13.3 and is the human homolog of the Drosophila "eyes absent" gene, which is involved in the development of all components of the inner ear. In the developing kidney, the gene is required for metanephric development, as reported above.

EYA1 mutations are detected in approximately $40 \%$ of patients with clinical diagnosis of BOR syndrome. An additional gene, SIXI (Drosophila sine oculis homologue), which interacts with EYA1 and PAX2 in a complex network of genes that control the development of kidneys, ears, and other organs, has been identified [16].

Townes-Brocks syndrome (TBS; OMIM 107480) is an autosomal dominantly inherited disorder, which comprises multiple defects, including imperforate anus, preaxial polydactyly, and/or triphalangeal thumbs and dysplastic ears. Further manifestations include renal anomalies such as hypo/dysplastic kidney and urinary tract malformations, foot malformations, congenital heart defects, and, rarely, mental retardation. Among urinary tract malformations reported in TBS, VUR has also been described [17]. Significant intra- and inter-familiar phenotypic variability has been noted and clinical features overlapping with BOR 
Table 1 Human syndromes with vesico-ureteric reflux $(V U R)$

\begin{tabular}{|c|c|c|c|c|}
\hline Syndromes & Kidney and urinary tract phenotype & Other associated abnormalities & $\begin{array}{l}\text { Inheritance } \\
\text { pattern }\end{array}$ & $\begin{array}{l}\text { Disrupted gene } \\
\text { product }\end{array}$ \\
\hline Acrorenal (Siegler) & $\begin{array}{l}\text { VUR, renal ectopia, HN, ureteral } \\
\text { atresia/stenosis }\end{array}$ & $\begin{array}{l}\text { SS, hypoplastic radii/ulnae/humeri, } \\
\text { oligodactyly }\end{array}$ & $\mathrm{U}$ & \\
\hline $\begin{array}{l}\text { Adrenal hypoplasia- } \\
\text { MR }\end{array}$ & VUR, HN, ureteral atresia/stenosis & $\begin{array}{l}\text { Aminoaciduria, MR, muscular } \\
\text { dystrophy, visual abnormality }\end{array}$ & $\mathrm{XL}$ & \\
\hline Bardet-Biedl & $\begin{array}{l}\text { VUR, renal cysts/dysplasia, duplicity, } \\
\text { HN, nephritis/sclerosis }\end{array}$ & $\begin{array}{l}\text { Obesity, polysyndactyly, MR, } \\
\text { retinopathy, hypogonadism }\end{array}$ & AR & $B B S 1-10$ \\
\hline Branchio-oto-renal & $\begin{array}{l}\text { VUR, renal agenesis, hypoplasia/ } \\
\text { dysplasia, duplicity, obstruction, HN }\end{array}$ & $\begin{array}{l}\text { Branchial remnant, preauricular pit/ } \\
\text { tag, microtia, deafness }\end{array}$ & $\mathrm{AD}$ & $E Y A 1$ or $S I X 1$ \\
\hline Cat eye & $\begin{array}{l}\text { VUR, renal agenesis, hypo/dysplasia, } \\
\text { duplicity, HN }\end{array}$ & $\begin{array}{l}\text { Atresia of colon, anus, genitalia, } \\
\text { vertebral defects, transesophageal } \\
\text { fistula }\end{array}$ & $\mathrm{C}$ & $\begin{array}{l}22 \text { partial } \\
\text { tetrasomy; inv dup } \\
(22)(\mathrm{q} 11)\end{array}$ \\
\hline $\begin{array}{l}\text { DiGeorge/ } \\
\text { velocardiofacial }\end{array}$ & VUR, renal hypoplasia, duplicity, HN & $\begin{array}{l}\text { Conotruncal CHD, thymic aplasia, } \\
\text { typical face, cleft palate }\end{array}$ & $\mathrm{C}$ & $22 q 11$ deletion \\
\hline $\begin{array}{l}\text { Ectrodactyly- } \\
\text { ectodermal dysplasia- } \\
\text { clefting }\end{array}$ & $\begin{array}{l}\text { VUR, renal agenesis, renal dysplasia, } \\
\text { cysts, HN }\end{array}$ & $\begin{array}{l}\text { Ectrodactyly, hypohidrosis, sparse } \\
\text { hair, cleft lip/palate }\end{array}$ & $\mathrm{AD}$ & \\
\hline Epstein & VUR & $\begin{array}{l}\text { Thrombocytopathia, nerve deafness, } \\
\text { cataract }\end{array}$ & $\mathrm{AD}$ & МYH9 \\
\hline $\begin{array}{l}\text { Goldenhar (oculo- } \\
\text { auriculo-vertebral) }\end{array}$ & $\begin{array}{l}\text { VUR, renal agenesis, renal dysplasia, } \\
\text { HN, duplicity }\end{array}$ & $\begin{array}{l}\text { Hemifacial microsomia, ear } \\
\text { anomalies, vertebral defects }\end{array}$ & $\mathrm{S}, \mathrm{AD}$ & \\
\hline $\begin{array}{l}\text { Hypoparathyroidism- } \\
\text { deafness-renal } \\
\text { dysplasia }\end{array}$ & VUR, renal hypoplasia, renal aplasia & Hypoparathyroidism, deafness & $\mathrm{AD}$ & GATA3 \\
\hline Kabuki & VUR, horseshoe kidney, duplicity, HN, & $\begin{array}{l}\text { MR, Kabuki-like face, large ears, } \\
\text { cleft palate }\end{array}$ & $\mathrm{U}$ & \\
\hline Kallmann & VUR, duplicity, renal agenesis & $\begin{array}{l}\text { Anosmia, cleft lip/palate, } \\
\text { hypogonadotrophic hypogonadism }\end{array}$ & $\begin{array}{l}\mathrm{XL}, \mathrm{AD} \\
\mathrm{AR}\end{array}$ & ANOSMIN-1 \\
\hline $\begin{array}{l}\text { Nager acrofacial } \\
\text { dysostosis }\end{array}$ & VUR, renal agenesis, HN, duplicity & $\begin{array}{l}\text { Facial bone hypoplasia, cleft eyelid, } \\
\text { radial ray defect }\end{array}$ & $\mathrm{AD}$ & ZFP37 \\
\hline $\begin{array}{l}\text { Polydactyly- } \\
\text { obstructive uropathy }\end{array}$ & VUR, HN, ureteral/urethra diverticulae & $\begin{array}{l}\text { Postaxial polydactyly of hands and } \\
\text { feet }\end{array}$ & $\mathrm{U}$ & \\
\hline Renal-coloboma & $\begin{array}{l}\text { VUR, renal hypoplasia/dysplasia, renal } \\
\text { agenesis }\end{array}$ & $\begin{array}{l}\text { Optic nerve coloboma, nerve } \\
\text { deafness }\end{array}$ & $\mathrm{AD}$ & $P A X 2$ \\
\hline Urogenital adysplasia & $\begin{array}{l}\text { VUR, renal agenesis, renal hypo/ } \\
\text { dysplasia, HN }\end{array}$ & $\begin{array}{l}\text { Abnormal uterus, deformity of feet } \\
\text { and hands }\end{array}$ & $\mathrm{AD}$ & \\
\hline $\begin{array}{l}\text { Renal/Müllerian } \\
\text { hypoplasia }\end{array}$ & $\begin{array}{l}\text { VUR, horseshoes kidney, renal } \\
\text { hypoplasia }\end{array}$ & $\begin{array}{l}\text { Absent uterus, broad forehead, DD, } \\
\text { large fontanel }\end{array}$ & $\mathrm{AR}$ & \\
\hline Townes-Brocks & $\begin{array}{l}\text { VUR, renal agenesis, renal dysplasia, } \\
\text { duplicity, ureteral/urethra diverticulae }\end{array}$ & $\begin{array}{l}\text { Triphalangeal thumb, imperforate } \\
\text { anus, skin tag, deafness }\end{array}$ & $\mathrm{AD}$ & $S A L L 1$ \\
\hline Wolfram & VUR, HN & $\begin{array}{l}\text { Diabetes mellitus/insipidus, optic } \\
\text { atrophy, nerve deafness }\end{array}$ & M & WFS1-2 \\
\hline
\end{tabular}

$A D$ autosomal dominant, $A R$ autosomal recessive, $C$ chromosomal, $C H D$ congenital heart disease, $D D$ development delay, $H N$ hydroureteronephrosis, $M$ mitochondrial, $M R$ mental retardation, $S$ sporadic, $S S$ short stature, $U$ uncertain, $X L$ X-linked (modified from [2]).

syndrome have been reported. TBS has been shown to result from mutation in the SALL1 (Drosophila sall homologue) gene, which maps on chromosome 16q12.1 and encodes a zinc finger protein thought to act as a transcriptional repressor (see above). The gene comprises three exons, containing four highly conserved double zinc finger domains. To date, 35 different mutations have been reported, mostly frameshift mutations occurring in exon 2 and found $5^{\prime}$ to or within the region encoding the first double zinc finger. SALL1 mutation analysis in TBS has failed as yet to demonstrate a clear genotype-phenotype correlation. One hypothesis is that SALL1 mutations cause TBS via haplo-insufficiency, as most of the observed mutations insert premature termination codons [18]. However, Sall1 heterozygous knock-out mice showed normal phenotype, while homozygous mutants had isolated kidney defects without other TBS manifestations. In other animal models, heterozygotes already showed a TBS-like pheno- 
type and TBS was considered to be caused by mutations leading to truncated protein with a dominant negative effect.

In hypoparathyroidism-sensorineural deafness and renal disease syndrome (HDR; OMIM 146255), urinary manifestations include renal aplasia or hypoplasia, pelvicaliceal deformity, and VUR. The type and severity of clinical manifestations may range over a wide phenotypic spectrum. The syndrome has an autosomal dominant pattern of inheritance, even though an autosomal recessive mode of inheritance has also been hypothesized. Hasegawa first described HDR syndrome in a girl with a de novo $10 \mathrm{p}$ deletion [19]. Subsequent molecular deletion analysis defined a critical region for the disease on 10p14-15. In this context, a zinc finger transcription factor, GATA3, has been mapped. Human GATA3 expression has been detected in the developing parathyroid glands, inner ears, kidney, thymus, and CNS. Gata3 null mutant mice show renal hypoplasia and developmental defects in structures derived from cephalic neural crest cells. Heterozygous human GATA3 abnormalities predicting a loss of function, namely one nonsense mutation, two intragenic deletions, and two whole gene deletions, have been identified in several families with HDR syndrome, suggesting that the haploinsufficiency of GATA3 is the major cause of the disease [20].

Primary isolated VUR: candidate gene identification by family studies

The increased sibling recurrence rates as well as parentoffspring transmission strongly implicate hereditary factors in the development of primary isolated VUR. The severity of VUR varies between affected individuals in a family and abnormalities often improve or can entirely resolve with age, making complete ascertainment of affected family members difficult. Moreover, asymptomatic individuals are rarely screened, as the diagnosis often requires invasive procedures. Finally, establishing the diagnosis of reflux nephropathy is equally problematic.

Nonetheless, familial clustering of isolated primary VUR and/or reflux nephropathy have been described and a broad range of inheritance patterns have been reported from family studies, including autosomal-dominant with incomplete penetrance, autosomal-recessive, sex-linked, and even multifactorial. Only Chapman et al.'s study used complex segregation analysis to determine the most likely genetic model. In that set of families, a single dominant gene was best able to explain the transmission of the trait [21].

More recently, multigenerational families with both VUR and reflux nephropathy were examined by genomewide linkage analysis by Feather et al. In 5 of the 7 families analyzed, VUR mapped to a locus on chromosome $1 \mathrm{p} 13$
[22]. In the other two families, no linkage was shown to this region, implicating additional genomic loci in VUR, and 12 additional loci were identified genome-wide with $p$ $>0.05$. No significant linkage was found to $6 \mathrm{p}$, an HLA locus hypothesized to increase the susceptibility to infection and progression to reflux nephropathy, or to $P A X 2$.

A candidate approach to test the association of primary VUR with already reported loci $(1 \mathrm{p} 13,3 \mathrm{p} 12,6 \mathrm{p} 21,10 \mathrm{q} 26$, and 19q13) did not yield any significant LOD scores [23].

Other authors identified a $13 \mathrm{q}$ deletion in several children affected by VUR and reported congenital anomalies of kidney and urinary tract (CAKUT)-associated locus on 13q12-22. These authors very recently described the results of cyto- and molecular genetic studies to identify a second region on chromosome 13 that is located on 13q3334 and is associated with CAKUT such as severe VUR and reflux nephropathy [24]. The critical region spans approximately $7 \mathrm{Mb}$ and includes 33 genes; in murine models, several of these genes show mRNA expression patterns that suggest their potential involvement in renal/urinary tract development anomalies.

Literature data support the hypothesis that VUR is genetically heterogeneous and is caused by different genes acting either alone or in combination, along with random environmental effects.

Is VUR a multifactorial complex disorder?

Multifactorial disorders result from complex interactions between a number of predisposing factors including the genotype and a variety of environmental exposures that trigger, accelerate, or exacerbate the disease process. In contrast to mendelian single-gene defects, there is only a handful of multifactorial diseases whose underlying genetic model is known. The major approach used to locate and identify genes that predispose to complex disease is association study, which compares the frequencies of particular alleles between affected and unaffected individuals, enabling the identification of high- and low-risk persons with a predisposition to complex disorders. This genetic analysis is performed using different polymorphisms (DNA variations) that are present at least in 1-2\% of normal individuals. In humans, association studies in the VUR-affected population have been performed by polymorphisms of the genes involved in kidney and urinary tract development previously identified in animal models [25].

The renin angiotensin system (RAS) appears to play an important role in renal development [26]. Angiotensinogen mutant mice have atrophic papillae with pelvic space enlargement, chronic interstitial inflammation and fibrosis, as well as ACE (angiotensin converting enzyme) and angiotensin II type 1 receptor (AGTR1) null mutant mice. 
Conversely, angiotensin II type 2 receptor (AGTR2) null mutant mice have urological disorders, including both obstructive anomalies and reflux, with or without renal hypo/dysplasia. On the basis of these experimental studies, several authors have hypothesized that genetic polymorphisms of the RAS components may be important factors in VUR-including CAKUT development and progression. However, the results of these studies are conflicting: polymorphisms in ACE and AGTR2 have been inconsistently associated with VUR, reflux nephropathy or combined kidney and urinary tract anomalies.

An analogous result has been demonstrated for Uroplakin genes. Uroplakins (UP) are a group of four membrane proteins that are synthesized by mammalian urothelium, the lining of most of the lower urinary tract, including the proximal urethra, bladder, ureter, and renal pelvis. Genetic ablation of UPIII causes VUR in mice [27]. In humans, UPIIIa heterozygous mutations cause renal adysplasia and severe VUR was described in two unrelated kindreds, one isolated and the other associated with a persistent cloaca [28]. In a population of 76 VUR patients, 18 single nucleotide polymorphisms (SNPs), seven of them missense, were found in all four UP genes, but only a weak association between the two UP polymorphisms and VUR was observed [29]. This suggests that missense changes of UP genes cannot play a dominant role in causing VUR in humans, although they may be weak risk factors contributing to complex polygenic disease.

\section{Conclusions}

Animal and human studies suggest that VUR and the associated renal dysplasia may result from a dysregulation of the complex gene network that regulates the normal developmental program of the kidneys and urinary tract. Molecular and genetic studies have greatly increased our understanding of VUR, but the human gene(s) responsible for primary VUR remain to be found. Future approaches to gene mapping technology will allow a better understanding of the genetic factors that underlie VUR.

Study Questions (Answers appear following the reference list)

Directions: Each of the numbered items is followed by several possible answers. Select the ONE lettered answer that is BEST in each case.

1. What percentage of chronic renal failure in pediatric patients is due to VUR?
a) $10 \%$
b) $40 \%$
c) $25 \%$

2. In which structures are $G d n f$ and Ret expressed during kidney development?

a) Both in metanephric mesenchyme

b) In metanephric mesenchyme and in the ureteric bud respectively

c) In the ureteric bud and in the cloaca

3. What is the prevalence of VUR in the siblings of VURaffected children?
a) $10 \%$
b) $40 \%$
c) $80 \%$

4. Which gene's mutation is responsible for BOR syndrome in humans?
a) $E Y A 1$
b) $P A X 2$
c) $W T 1$

5. What is the prevalence of gene polymorphisms in the general population?
a) $<1 \%$
b) $>1 \%$
c) $>5 \%$

\section{References}

1. Mak RH, Kuo HJ (2003) Primary ureteral reflux: emerging insights from molecular and genetic studies. Curr Opin Pediatr 15:181-185

2. Avner ED, Harmon WE, Niaudet P (2004) Pediatric nephrology, 5th edn. Lippincott Williams and Wilkins, Baltimore, pp 1027 1048

3. Murawski IJ, Gupta IR (2006) Vesicoureteric reflux and renal malformations: a developmental problem. Clin Genet 69:105-117

4. Ichikawa I, Kuwayama F, Pope JC 4th, Stephens FD, Miyazaki Y (2002) Paradigm shift from classic anatomic theories to contemporary cell biological views of CAKUT. Kidney Int 61:889-898

5. Woolf AS, Winyard PJ (2002) Molecular mechanisms of human embryogenesis: developmental pathogenesis of renal tract malformations. Pediatr Dev Pathol 5:108-129

6. Brodbeck S, Englert C (2004) Genetic determination of nephrogenesis: the Pax/Eya/Six gene network. Pediatr Nephrol 19:249255

7. Murer L, Caridi G, Della Vella M, Montini G, Carasi C, Ghiggeri G, Zacchello G (2002) Expression of nuclear transcription factor PAX2 in renal biopsies of juvenile nephronophtisis. Nephron 91:588-593

8. Vainio S, Lin Y (2002) Coordinating early kidney development: lessons from gene targeting. Nat Rev Genet 3:108-129

9. Piscione TD, Rosenblum ND (2002) The molecular control of renal branching morphogenesis: current knowledge and emerging insights. Differentiation 70:227-246

10. Dressler GR, Wilkinson JE, Rothenpieler UW, Patterson LT, Williams-Simons L, Westphal H (1993) Deregulation of Pax2 expression in transgenic mice generates severe kidney abnormalities. Nature 362:65-67

11. Heale WF (1997) Hereditary vesicoureteric reflux: phenotypic variation and family screening. Pediatr Nephrol 11:504-507 
12. Sanyanusin P, McNoe LA, Sullivan MJ, Weaver RG, Eccles MR (1995) Mutations of PAX2 in two siblings with renal-coloboma syndrome. Hum Mol Genet 4:2183-2184

13. Favor J, Sandulache R, Neuhauser-Klaus A, Pretsch W, Chatterjee B, Senft E, Wurst W, Blanquet V, Grimes P, Sporle R, Schughart K (1996) The mouse Pax21Neu mutation is identical to a human PAX2 mutation in a family with renal-coloboma syndrome and results in developmental defects of the brain, ear, eye and kidney. Proc Natl Acad Sci USA 93:13870-13875

14. Eccles MR, Bailey RR, Abbott GD, Sullivan MJ (1996) Unravelling the genetics of vesicoureteric reflux: a common familial disorder. Hum Mol Genet 5:1425-1429

15. Abdelhak S, Kalatzis V, Heilig R, Compain S, Samson D, Vincent C, Weil D, Cruaud C, Sahly I, Leibovici M, Bitner-Glindzicz M, Francis M, Lacombe D, Vigneron J, Charachon R, Boven K, Bedbeder P, Van Regemorter N, Weissenbach J, Petit C (1997) A human homologue of the Drosophila eyes absent gene underlies branchio-oto-renal (BOR) syndrome and identifies a novel gene family. Nat Genet 15:157-164

16. Ruf RG, Berkman J, Wolf MT, Nurnberg P, Gattas M, Ruf EM, Hyland V, Kromberg J, Glass I, Macmillan J, Otto E, Nurnberg G, Lucke B, Hennies HC, Hildebrandt F (2003) A gene locus for branchio-otic syndrome maps to chromosome 14q21.3-q24.3. J Med Genet 40:515-519

17. Botzenhart EM, Green A, Ilyina H, Konig R, Lowry RB, Lo IFM, Shohat M, Burke L, McGaughran J, Chafai R, Pierquin G, Michaelis RC, Whiteford ML, Simola KOJ, Rosler B, Kohlhase J (2005) SALL1 mutation analysis in Townes-Brocks syndrome: twelve novel mutations and expansion of the phenotype. Hum Mutat 26:282

18. Kohlhase J (2000) SALL1 mutations in Townes-Brocks syndrome and related disorders. Hum Mutat 16:460-466

19. Hasegawa T, Hasegawa $Y$, Aso T, Koto S, Nagai T, Tsuchiya $Y$, Kim KC, Ohashi H, Wakui K, Fukushima Y (1997) HDR syndrome (hypoparathyroidism, sensorineural deafness, renal dysplasia) associated with $\operatorname{del}(10)(\mathrm{p} 13)$. Am J Med Genet 73:416-418

20. Barakat AY, D'Albora JB, Martin MM, Jose PA (1977) Familial nephrosis, nerve deafness, and hypoparathyroidism. J Pediatr 91:61-64

21. Chapman CJ, Bailey RR, Janus ED, Abbott GD, Lynn KL (1985) Vesicoureteric reflux: segregation analysis. Am J Med Genet 20:577-584

22. Feather SA, Malcolm S, Woolf AS, Wright V, Blaydon D, Reid CJD, Flinter FA, Proesmans W, Devriendt K, Carter J, Warwicker P, Goodship THJ, Goodship JA (2000) Primary, nonsyndromic ves- icoureteric reflux and its nephropathy is genetically heterogeneous, with a locus on chromosome 1. Am J Hum Genet 66:1420-1425

23. Sanna-Cherchi S, Reese A, Hensle T, Caridi G, Izzi C, Kim YY, Konka A, Murer L, Scolari F, Ravazzolo R, Ghiggeri GM, Gharavi A (2005) Familial vesicoureteral reflux: testing replication of linkage in seven new multigenerational kindreds. J Am Soc Nephrol 16:1781-1787

24. Vats KR, Ishwad C, Singla I, Vats A, Ferrell R, Ellis D, Moritz M, Surti U, Jayakar P, Frederick DR, Vats AN (2006) A locus for renal malformations including vesico-ureteric reflux on chromosome 13q33-34. J Am Soc Nephrol 17:1158-1167

25. Artifoni L, Negrisolo S, Montini G, Zucchetta P, Molinari PP, Cassar W, Destro R, Anglani F, Rigamonti W, Zacchello G, Murer L (2007) Interleukin-8 and CXCR1 receptor functional polymorphisms and susceptibility to acute pyelonephritis. J Urol in press

26. Yosypiv IV, El-Dahr SS (2005) Role of the renin-angiotensin system in the development of the ureteric bud and renal collecting system. Pediatr Nephrol 20:1219-1229

27. Hu P, Deng FM, Liang FX, Hu CM, Auerbach A, Shapiro E, Wu XR, Kachar B, Sun TT (2000) Ablation of uroplakin III gene results in small urothelial plaques, urothelial leakage, and vesicoureteral reflux. J Cell Biol 151:961-971

28. Jenkins D, Bitner-Glindzicz M, Malcolm S, Hu CC, Allison J, Winyard PJ, Gullett AM, Thomas DF, Belk RA, Feather SA, Sun TT, Woolf AS (2005) De novo Uroplakin IIIa heterozygous mutations cause human renal adysplasia. J Am Soc Nephrol 16:214-219

29. Jiang S, Gitlin J, Deng FM, Liang FX, Lee A, Atala A, Bauer SB, Ehrlich GD, Feather SA, Goldberg JD, Goodship JA, Goodship TH, Hermanns M, Hu FZ, Jones KE, Malcolm S, Mendelsohn C, Preston RA, Retik AB, Schneck FX, Wright V, Ye XY, Woolf AS, Wu XR, Ostrer H, Shapiro E, Yu J, Sun TT (2004) Lack of major involvement of human uroplakin genes in vesicoureteral reflux: implications for disease heterogeneity. Kidney Int 66:10-19

30. Pope JC 4th, Brock JW 3rd, Adams MC, Stephens FD, Ichikawa I (1999) How they begin and they end: classic and new theories for the development and deterioration of congenital anomalies of the kidney and urinary tract, CAKUT. J Am Soc Nephrol 10:2018-2028
Answers:
1. c)
2. b)
3. b)
4. a)
5. b) 